\title{
Titanium-Tissue Interface Reaction and Its Control With Surface Treatment
}

\author{
Takao Hanawa* \\ Department of Metallic Biomaterials, Institute of Biomaterials and Bioengineering, Tokyo Medical and Dental University, \\ Tokyo, Japan
}

OPEN ACCESS

Edited by:

Hasan Uludag,

University of Alberta, Canada

Reviewed by:

Kathryn Grandfield,

McMaster University, Canada

Diego Mantovani,

Laval University, Canada

*Correspondence:

Takao Hanawa

hanawa.met@tmd.ac.jp

Specialty section:

This article was submitted to

Biomaterials,

a section of the journal Frontiers in Bioengineering and

Biotechnology

Received: 12 February 2019

Accepted: 03 July 2019

Published: 17 July 2019

Citation:

Hanawa T (2019) Titanium-Tissue Interface Reaction and Its Control With Surface Treatment.

Front. Bioeng. Biotechnol. 7:170. doi: 10.3389/fbioe.2019.00170
Titanium (Ti) and its alloys are widely used for medical and dental implant devices - artificial joints, bone fixators, spinal fixators, dental implant, etc. - because they show excellent corrosion resistance and good hard-tissue compatibility (bone formation and bone bonding ability). Osseointegration is the first requirement of the interface structure between titanium and bone tissue. This concept of osseointegration was immediately spread to dental-materials researchers worldwide to show the advantages of titanium as an implant material compared with other metals. Since the concept of osseointegration was developed, the cause of osseointegration has been actively investigated. The surface chemical state, adsorption characteristics of protein, and bone tissue formation process have also been evaluated. To accelerate osseointegration, roughened and porous surfaces are effective. $\mathrm{HA}$ and $\mathrm{TiO}_{2}$ coatings prepared by plasma spray and an electrochemical technique, as well as alkalinization of the surface, are also effective to improve hard-tissue compatibility. Various immobilization techniques for biofunctional molecules have been developed for bone formation and prevention of platelet and bacteria adhesion. These techniques make it possible to apply Ti to a scaffold of tissue engineering. The elucidation of the mechanism of the excellent biocompatibility of Ti can provide a shorter way to develop optimal surfaces. This review should enhance the understanding of the properties and biocompatibility of $\mathrm{Ti}$ and highlight the significance of surface treatment.

Keywords: titanium, titanium alloy, biocompatibility, biofunction, bone formation, bone bonding, surface treatment, surface morphology

\section{INTRODUCTION}

Many medical devices made of metals have been substituted by those made of ceramics and polymers during the past half century because of innovation in ceramics and polymers and their excellent biocompatibility and biofunction, as shown in Figure 1. Despite this situation, more than $70 \%$ of surgical implant devices, especially more than $95 \%$ of orthopedic implants (calculated based on statics from the Ministry of Health, Labor and Welfare, Japan), still consist of metals because of the large fracture toughness and durability of metals. In particular, titanium (Ti) materials, such as commercially pure titanium (CP Ti) and Ti alloys are widely used in medicine and dentistry because of their large corrosion resistance, large specific strength, and high performance in medicine and dentistry (Brunette et al., 2001). Their good interfacial and chemical compatibility against tissues are well-known based on substantial evidence from basic research and high clinical performances. However, the mechanism of the excellent biocompatibility of Ti among metals is not completely 


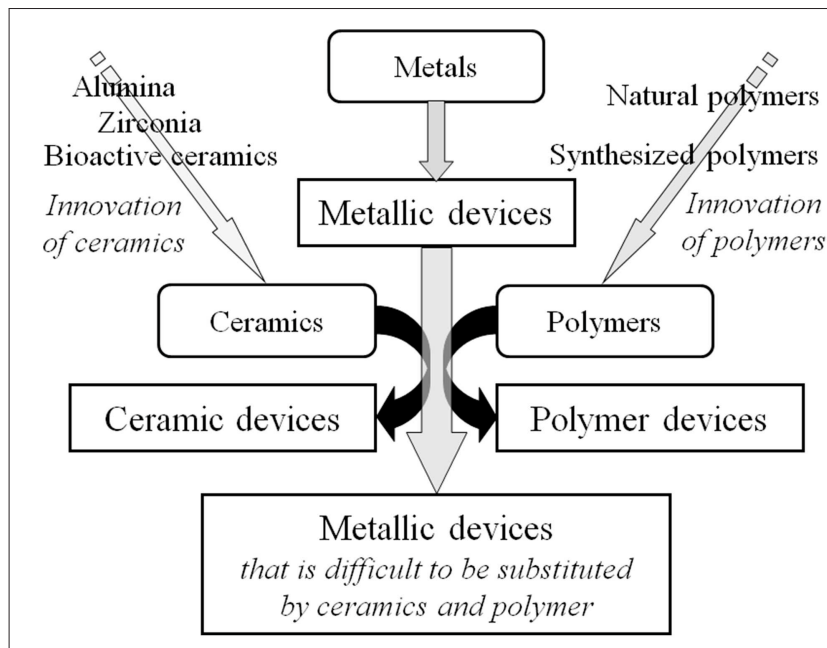

FIGURE 1 | Substitution of metallic devices by ceramic devices and polymer devices due to innovation of ceramics and polymers.

understood. After a metallic material is implanted into a human body, a reaction immediately occurs between the living tissue and the material surface. In other words, the first reaction at the interface directly influences the material's biocompatibility. The Young's modulus of $\alpha+\beta$-type Ti alloy (100-111 GPa) is half those of type $316 \mathrm{~L}$ stainless steel $(200 \mathrm{GPa})$ and Cobalt (Co)chromium (Cr)-molybdenum (Mo) alloy ( 220 GPa), which is a large advantage to prevent stress shielding in bone plates and stems of artificial hip joints in orthopedics. In addition, the magnetic susceptibilities of $\mathrm{Ti}\left(31.9 \times 10^{-9} \mathrm{~m}^{3} \mathrm{~kg}^{-1}\right)$ and Ti-6Al-4V ELI alloy $\left(39.8 \times 10^{-9} \mathrm{~m}^{3} \mathrm{~kg}^{-1}\right)$ are much smaller than that of Co-Cr-Mo alloy $\left(94.5 \times 10^{-9} \mathrm{~m}^{3} \mathrm{~kg}^{-1}\right)$, as well as stainless steels, decreasing the influences of magnetic resonance imaging (MRI), such as motion, attraction force, torque, heat generation, and artifacts. This property is significant, because MRI is commonly used for medical examination.

A disadvantage of metals for use as biomaterials is that they are artificial materials, and metals do not have biofunction. To promote biocompatibility and add biofunction to metals, surface modification or surface treatment is necessary, because biocompatibility is not promoted and biofunction is not added through conventional manufacturing processes, such as melting, casting, forging, and heat treatment. Surface treatment is a process that changes surface morphology, structure, and composition, leaving the bulk mechanical properties. In orthopedics, bone bonding is required in the stem and acetabular cup of artificial hip joints. In the case of dentistry, hardtissue compatibility for bone formation and bone bonding, softtissue compatibility for adhesion of gingival epithelium, and an antibacterial property for the inhibition of bacterial invasion are required in dental implants. For these purposes, a variety of surface treatment techniques have been investigated at the research level, and some of them have been commercialized.

In this overview, a brief history of $\mathrm{CP} \mathrm{Ti}$ and $\mathrm{Ti}$ alloys, the application of $\mathrm{Ti}$ to medical devices (including dental devices), their use and tasks in medicine, proposed mechanisms of excellent biocompatibility of $\mathrm{Ti}$, and surface treatment to improve biocompatibility and to add biofunction are reviewed. This review is intended to enhance the understanding of the properties and biocompatibility of $\mathrm{Ti}$ and the significance of surface treatment, including surface-morphological alteration.

\section{HISTORY OF APPLICATION TO MEDICINE}

The history of the application of CP Ti and Ti alloys to medicine and dentistry is summarized in Table 1. The first report on CP Ti for medicine was appeared in 1940, and excellent bone compatibility was found based on an animal test (Bothe et al., 1940). Thereafter, the compatibility to bone and soft tissue of rabbits (Leventhal, 1951), its non-cytotoxicity due to excellent corrosion resistance in biological environments (Beder et al., 1957), and excellent biocompatibility in dogs were reported. The large-scale industrial manufacturing process for $\mathrm{Ti}$ achieved in the last half 1940s made it possible to conduct many studies for medical applications, revealing excellent biocompatibility in long-term animal testing (Williams, 1982a). Thereafter, the usefulness of $\mathrm{CP}$ Ti was widely recognized by the last half 1960s through clinical evaluation (Pillar and Weatherly, 1982; Williams, 1982a,b).

However, to avoid the fracture of $\mathrm{CP} \mathrm{Ti}$ in the human body, an aerospace $\mathrm{Ti}-6 \mathrm{Al}-4 \mathrm{~V}$ alloy was diverted to artificial joints and bone fixators (Pillar and Weatherly, 1982; Williams, 1982a,b). Thereafter, vanadium (V)- and/or aluminum (Al)-free $\alpha+\beta$-type Ti alloys and $\beta$-type Ti alloys with low Young's modulus have been developed. $\mathrm{V}$ that creates the cytotoxicity of $\mathrm{Ti}-6 \mathrm{Al}-4 \mathrm{~V}$ alloy was replaced by niobium $(\mathrm{Nb})$, which is a safe element, to develop a new $\alpha+\beta$-type $\mathrm{Ti}-6 \mathrm{Al}-7 \mathrm{Nb}$ alloy (Semlitsch and Staub, 1985; Li et al., 2010). Other $\alpha+\beta$-type alloys, $\mathrm{Ti}-6 \mathrm{Al}-2.5$ iron $(\mathrm{Fe})$ alloy and $\mathrm{Ti}-6 \mathrm{Al}-2 \mathrm{Nb}-1$ tantalum (Ta)-0.8Mo alloy, were developed in 1970s (Rao and Houska, 1979; Anon, 1994).

On the other hand, $\beta$-type Ti alloys for medical use have been developed. Ti-13zirconium $(\mathrm{Zr})-13 \mathrm{Ta}$ alloy (nearly $\beta$ ) has been developed in the United States. Various $\beta$-type alloys, $\mathrm{Ti}-12 \mathrm{Mo}-6 \mathrm{Zr}-2 \mathrm{Fe}$ alloys (Wang et al., 1993), T-15Mo (Zardiackas et al., 1996), and $\mathrm{Ti}-15 \mathrm{Mo}-2.8 \mathrm{Nb}-0.2$ silicon (Si)-0.28oxygen (O) (Fanning, 1996), have been developed in the United States. $\mathrm{Ti}-15 \mathrm{Mo}-5 \mathrm{Zr}$ and $\mathrm{Ti}-15 \mathrm{Mo}-5 \mathrm{Zr}-3 \mathrm{Al}$ alloys (Rao and Houska, 1979; Matsuda et al., 1997) and $\mathrm{Ti}-15 \mathrm{Zr}-4 \mathrm{Nb}-4 \mathrm{Ta}$ alloy (Okazaki, 2001) have been developed in Japan. The history of the development of $\beta$-type Ti alloys is well-summarized elsewhere (Niinomi, 2019). Young's modulus could decrease to $40-60 \mathrm{GPa}$ in a $\beta$-type alloy.

Since 2000, a new wave of the development of Ti alloys has been generated. The design of Ti alloys through twinninginduced plasticity (TWIP) and transformation-induced plasticity (TRIP) has been attempted, making it possible to develop novel $\beta$-metastable Ti alloys (Marteleur et al., 2012; Ahmed et al., 2016: Brozek et al., 2016; Zhan et al., 2016; Zhang et al., 2017; Lai et al., 2018). The TRIP and TWIP concepts were first invented in the field of steels and applied to Ti alloys through Ti-nickel (Ni) shape memory alloy. It is possible that this design will be applied to biomedical alloys in the near future. 
TABLE 1 | History of titanium application to medicine and development of titanium alloys.

\begin{tabular}{|c|c|c|c|}
\hline Year & Material & Circumstance & References \\
\hline 1940 & $\mathrm{Ti}$ & $\begin{array}{l}\text { Confirmation of equivalent biocompatibility as stainless } \\
\text { steel and cobalt-chromium alloy with animal test }\end{array}$ & Bothe et al., 1940 \\
\hline 1940 & $\mathrm{Ti}$ & Success of smelting by Kroll process & Kroll, 1940 \\
\hline 1948 & $\mathrm{Ti}$ & Launching industrial production & \\
\hline 1951 & $\mathrm{Ti}$ & $\begin{array}{l}\text { Confirmation of both soft and hard tissues compatibility } \\
\text { with animal test }\end{array}$ & Leventhal, 1951 \\
\hline 1957 & $\mathrm{Ti}$ & Confirmation of non-toxicity with long-term implantation & Beder et al., 1957 \\
\hline 1959 & $\mathrm{Ti}-\mathrm{Ni}$ & Development of shape memory alloy in USA & Buehler et al., 1963; Wang et al., 1965 \\
\hline 1960 & $\mathrm{Ti}$ & Excellent results in artificial joints & Williams, 1982a \\
\hline 1960's & $\mathrm{Ti}$ & Marketing as surgical implants in UK and USA & \\
\hline 1970's & $\mathrm{Ti}-6 \mathrm{Al}-4 \mathrm{~V}$ & Diverting aircraft material to orthopedic implants & \\
\hline 1978 & $\mathrm{Ti}-\mathrm{Cu}-\mathrm{Ni}$ & Trial of dental casting & Waterstrat et al., 1978 \\
\hline 1980 & $\mathrm{Ti}-5 \mathrm{Al}-2.5 \mathrm{Fe}$ & Development in Europe & \\
\hline 1982 & $\mathrm{Ti}$ & $\begin{array}{l}\text { Development of investment material and casting } \\
\text { machine for dental casting }\end{array}$ & Miura and Ida, 1988 \\
\hline 1985 & $\mathrm{Ti}-6 \mathrm{Al}-7 \mathrm{Nb}$ & Development in Switzerland & Semlitsch and Staub, 1985 \\
\hline 1993 & $\mathrm{Ti}-13 \mathrm{Nb}-13 \mathrm{Zr}$ & Development in USA & \\
\hline 1993 & $\mathrm{Ti}-12 \mathrm{Mo}-6 \mathrm{Zr}-2 \mathrm{Fe}$ & Development in USA & Wang et al., 1993 \\
\hline 1996 & $\mathrm{Ti}-15 \mathrm{Mo}$ & Development in USA & Zardiackas et al., 1996 \\
\hline 1988 & $\mathrm{Ti}-29 \mathrm{Nb}-13 \mathrm{Ta}-4.6 \mathrm{Zr}$ & Development in Japan & Kuroda et al., 1988 \\
\hline Around 2000 & $\mathrm{Ti}-15 \mathrm{Mo}-5 \mathrm{Zr}-3 \mathrm{Al}$ & Development in Japan & $\begin{array}{l}\text { Rao and Houska, 1979; Matsuda et al., } \\
1997\end{array}$ \\
\hline Around 2000 & $\mathrm{Ti}-6 \mathrm{Al}-2 \mathrm{Nb}-1 \mathrm{Ta}-0.8 \mathrm{Mo}$ & Development in Japan & Okazaki, 2001 \\
\hline 2004 & $\mathrm{Ti}-15 \mathrm{Zr}-4 \mathrm{Nb}-4 \mathrm{Ta}$ & Development in Japan & Ozaki et al., 2004 \\
\hline After 2000 & $\beta$-metastable alloys based on TRIP and TWIP & Development in mainly China & $\begin{array}{l}\text { Marteleur et al., 2012; Ahmed et al., 2016: } \\
\text { Brozek et al., 2016; Zhan et al., 2016; } \\
\text { Zhang et al., 2017; Lai et al., } 2018\end{array}$ \\
\hline
\end{tabular}

In dentistry, $\mathrm{CP} \mathrm{Ti}$ has been successfully used for dental implants since 1965 (Waterstrat et al., 1978), and the excellent hard-tissue compatibility is well-known. A magnesia-system investment material and argon-arc casting machine were developed in 1982, followed by the development of various dental casting systems for dental restoratives (Miura and Ida, 1988).

The development of new $\mathrm{Ti}$ alloys for medical devices continuously challenges by researchers, and new designs have been attempted based on d-electron alloy design theory (Kuroda et al., 1988) and the TRIP and TWIP concept.

\section{MEDICAL APPLICATION AND TASKS OF TITANIUM}

Because of the excellent properties of $\mathrm{CP} \mathrm{Ti}$ and $\mathrm{Ti}$ alloy as biomaterials, they are used for devices requiring strength, elongation, and long-term bone bonding in orthopedics, cardiovascular medicine, dentistry, etc. The specifications of $\mathrm{Ti}$ alloys used for medicine are listed in Table 2. Medical devices and $\mathrm{CP} \mathrm{Ti}$ and $\mathrm{Ti}$ alloys are listed in Table 3, and problems of CP Ti and $\mathrm{Ti}$ alloys in medicine are summarized in Table 4.

$\mathrm{Ti}$ alloys are used in orthopedics for artificial joints, bone fixators, spinal fixators, etc., receiving large mechanical stress. Bone absorption caused by stress shielding sometimes appears in bone fixators and artificial hip joints. Because load is mainly applied to the metal plate and stem, less load is applied to cortical bone by the difference in Young's modulus between metal and cortical bone (Gefen, 2002). If the Young's modulus of the metal plate is similar to that of cortical bone, load is equally applied to both metal and bone to prevent bone absorption. In this sense, $\beta$ type Ti alloys showing a lower Young's modulus are more suitable than $\alpha+\beta$-type alloys. Therefore, $\beta$-type Ti alloys consisting of Group 4 and 5 elements in the periodic table have continued to be designed and developed.

However, bone screws and bone nails made of $\mathrm{Ti}$ alloys form calluses and assimilate to bone tissue, forming calluses, during implantation, so bone is sometimes refractured when the devices are retrieved (Sanderson et al., 1992). Therefore, when the devices must be retrieved after healing, devices made of $316 \mathrm{~L}-$ type stainless steel are selected. This assimilation occurs because of the excellent hard-tissue compatibility of Ti alloys. A proper surface treatment may inhibit bone formation and bonding of $\mathrm{Ti}$ alloys contacting bone tissue.

In spinal surgery and maxillofacial surgery, the rod and plate of $\mathrm{Ti}$ alloys are sometimes bent by medical doctors in the operation room. These operations sometimes generate crack or fracture of Ti alloys, because the elongation to fracture of $\alpha+\beta$ type Ti alloy (10\% of Ti-6Al-4V ELI; Brunette et al., 2001) is much smaller than that of 316L-type stainless steel (40\%; ASTM 
TABLE 2 | Specification of titanium alloys for medical use.

\begin{tabular}{lllll}
\hline $\begin{array}{l}\text { Composition } \\
\text { (mass\%) }\end{array}$ & Type & ASTM & ISO & JIS \\
\hline Ti-5Al-2.5Fe & $\alpha+\beta$ & - & & \\
Ti-6Al-4V & $\alpha+\beta$ & F1108 (Cast) & ISO 5832-10 & \\
& & ISO 5832-3 & T7401-2 (Wrought) \\
Ti-6Al-4V ELI & $\alpha+\beta$ & F136 (Wrought) & ISO 5832-3 & - \\
Ti-6Al-2Nb-1Ta & $\alpha+\beta$ & - & - & T7401-3 \\
T-15Zr-4Nb-4Ta & $\alpha+\beta$ & - & - & T7401-4 \\
Ti-6Al-7Nb & $\alpha+\beta$ & F1295 & ISO 5832-11 & T7401-5 \\
Ti-3Al-2.5V & $\alpha+\beta$ & F2146 & & \\
Ti-6Al-2Nb-1Ta- & $\alpha+\beta$ & F136 & ISO 5832-14 & \\
$0.8 \mathrm{Mo}$ & & & & \\
Ti-13Nb-13Zr & Near $\beta$ & F1713 & - & \\
Ti-15Mo & $\beta$ & F2066 & - & \\
Ti-12Mo-6Zr-2Fe & $\beta$ & F1813 & - & \\
Ti-15Mo-5Zr-3Al & $\beta$ & F136 & ISO 5832-14 & T7401-6 \\
Ti-55.8Ni & Intermetallic & ASTM F 2063 & & T7404 \\
& compound & & & \\
\hline
\end{tabular}

A240). Therefore, the strengthening of $\alpha+\beta$-type Ti alloy while maintaining elongation is required.

$\mathrm{Ti}-\mathrm{Ni}$ alloy is used as guidewires and self-expanding stents. However, 37.2\% (45 of 121 cases) of Ti-Ni stents are fractured in 10.7 months of service (Scheinert et al., 2005). Corrosion may be related to the fracture, while the main cause is fatigue. In the case of stent grafts of $\mathrm{Ti}-\mathrm{Ni}$, severe pitting and crevice corrosion appears by the acceleration of corrosion due to the crevice between Ti-Ni alloy and a polymer as an artificial blood vessel (Heintz et al., 2001). Therefore, Ni-free Ti-based superelastic alloys have been researched (Shinohara et al., 2015).

In dentistry, the fixture part of dental implants consists of $\mathrm{CP} \mathrm{Ti}$ and Ti alloys to bond alveolar bone. A Ti-Ni superelastic alloy and a Ti-Mo alloy are used as orthodontic arch wire. In particular, $\mathrm{Ti}-\mathrm{Ni}$ alloy is widely used, because proper and continuous orthodontic force remains for a long time. Ti-Ni alloy is suitable for reamers and files for endodontics for bending tooth roots, while the alloy sometimes fractures from an overload with dental engines.

Corrosion of metallic implant devices implanted into the human body has been studied (Nakayama et al., 1989; Brunette et al., 2001; Alves et al., 2009; Asri et al., 2017; Manam et al., 2017; Eliaz, 2019), because the corrosion is related to toxicity and fracture, whereas examples of corrosion-fracture of metal implants are few. The reason is because the retrieval case of implants is limited, and surgeons are rarely interested in corroded retrieved implants. In particular, severe corrosion cases of $\mathrm{CP} \mathrm{Ti}$ and Ti alloys are rare. However, Ti used as dental restoratives is corroded by fluorine compounds contained in mouthwashes and dental pastes (Nakagawa et al., 1999). Microbial corrosion of Ti in the oral cavity has also been studied (Fukushima et al., 2014). The corrosion phenomena of metallic biomaterials including $\mathrm{Ti}$ alloys are reviewed (Manam et al., 2017; Eliaz, 2019), while the case of Ti alloys is rare.

As described above, $\mathrm{CP} \mathrm{Ti}$ and $\mathrm{Ti}$ alloys are widely used in medicine and dentistry because of their lightness, high
TABLE 3 | Medical devices consisting of titanium and titanium alloys.

\begin{tabular}{|c|c|c|}
\hline $\begin{array}{l}\text { Clinical } \\
\text { department }\end{array}$ & Medical device & $\mathrm{CP} \mathrm{Ti}$ and $\mathrm{Ti}$ alloy \\
\hline \multirow[t]{4}{*}{ Orthopedics } & Spinal fixator & CP Ti; Ti-6Al-4V; Ti-6Al-7Nb \\
\hline & $\begin{array}{l}\text { Bone fixator (bone plate, } \\
\text { screw, wire, bone nail, mini } \\
\text { palate, etc.) }\end{array}$ & CP Ti; Ti-6Al-4V; Ti-6Al-7Nb \\
\hline & Artificial joint; artificial head & $\begin{array}{l}\text { Ti-6Al-4V; Ti-6Al-7Nb; } \\
\text { Ti-15Mo-5Zr-3Al; } \\
\text { Ti-6Al-2Nb-1Ta-0.8Mo }\end{array}$ \\
\hline & Spinal spacer & $\mathrm{Ti}-6 \mathrm{Al}-4 \mathrm{~V} ; \mathrm{Ti}-6 \mathrm{Al}-7 \mathrm{Nb}$ \\
\hline \multirow[t]{6}{*}{$\begin{array}{l}\text { Cardiovascular } \\
\text { department }\end{array}$} & $\begin{array}{l}\text { Implantable artificial heart } \\
\text { (housing) }\end{array}$ & $\mathrm{CP} \mathrm{Ti}$ \\
\hline & $\begin{array}{l}\text { Heart pacemaker (case) } \\
\text { (electrode) } \\
\text { (terminal) }\end{array}$ & $\begin{array}{l}\text { CP Ti; Ti-6Al-4V } \\
\text { CP Ti } \\
\text { CP Ti }\end{array}$ \\
\hline & Artificial valve (flame) & $\mathrm{Ti}-6 \mathrm{Al}-4 \mathrm{~V}$ \\
\hline & Vascular stent & $\mathrm{Ti}-\mathrm{Ni}$ \\
\hline & Guide wire & $\mathrm{Ti}-\mathrm{Ni}$ \\
\hline & Cerebral aneurysm clip & CP Ti; Ti-6Al-4V \\
\hline \multirow[t]{3}{*}{ Dentistry } & $\begin{array}{l}\text { Inlay; crown; bridge; clasp; } \\
\text { denture base }\end{array}$ & CP Ti; Ti-6Al-7Nb \\
\hline & Dental implant & CP Ti; Ti-6Al-4V; Ti-6Al-7Nb \\
\hline & Orthodontic wire & Ti-Ni; Ti-Mo \\
\hline \multirow[t]{2}{*}{ General surgery } & $\begin{array}{l}\text { Surgical instrument (scalpel; } \\
\text { tweezer; scissor; drill) }\end{array}$ & $\mathrm{CP} \mathrm{Ti}$ \\
\hline & Catheter & $\mathrm{Ti}-\mathrm{Ni}$ \\
\hline
\end{tabular}

TABLE 4 | Problem to be solved in titanium and titanium alloys for medical use.

\begin{tabular}{|c|c|c|}
\hline Problem & Material & Medical device \\
\hline Stress shielding & $\alpha+\beta$ type Ti alloy & $\begin{array}{l}\text { Bone plate; stem of artificial } \\
\text { hip joint }\end{array}$ \\
\hline Adhesion to bone & Whole Ti alloy & Bone screw; bone nail \\
\hline $\begin{array}{l}\text { Cracking and fracture by } \\
\text { excessive deformation }\end{array}$ & CP Ti, $\alpha+\beta$ type Ti alloy & Spinal rod; maxillofacial plate \\
\hline Crevice corrosion; pitting & Ti-Ni alloy & Stent graft \\
\hline Fracture & Ti-Ni alloy & Endodontic file \\
\hline Corrosion with fluoride & CP Ti; whole Ti alloy & Dental restorative \\
\hline Cytotoxicity & CP Ti; whole Ti alloy & All devices \\
\hline Peri-implantitis & CP Ti; whole Ti alloy & $\begin{array}{l}\text { Abutment of dental implant; } \\
\text { orthodontic implant anchor; } \\
\text { percutaneous device; screw } \\
\text { of external bone fixator }\end{array}$ \\
\hline
\end{tabular}

corrosion resistance, and excellent biocompatibility compared with other metals.

\section{BIOCOMPATIBILITY OF TITANIUM}

Biocompatibility is defined as "the ability of a material to perform with an appropriate host response in a specific application" (William, 1987). The biocompatibility of a material is governed by initial and continuous reactions between the material and host body: adsorption of molecules, protein adsorption, cell adhesion, bacterial adhesion, activation of macrophage, formation of 


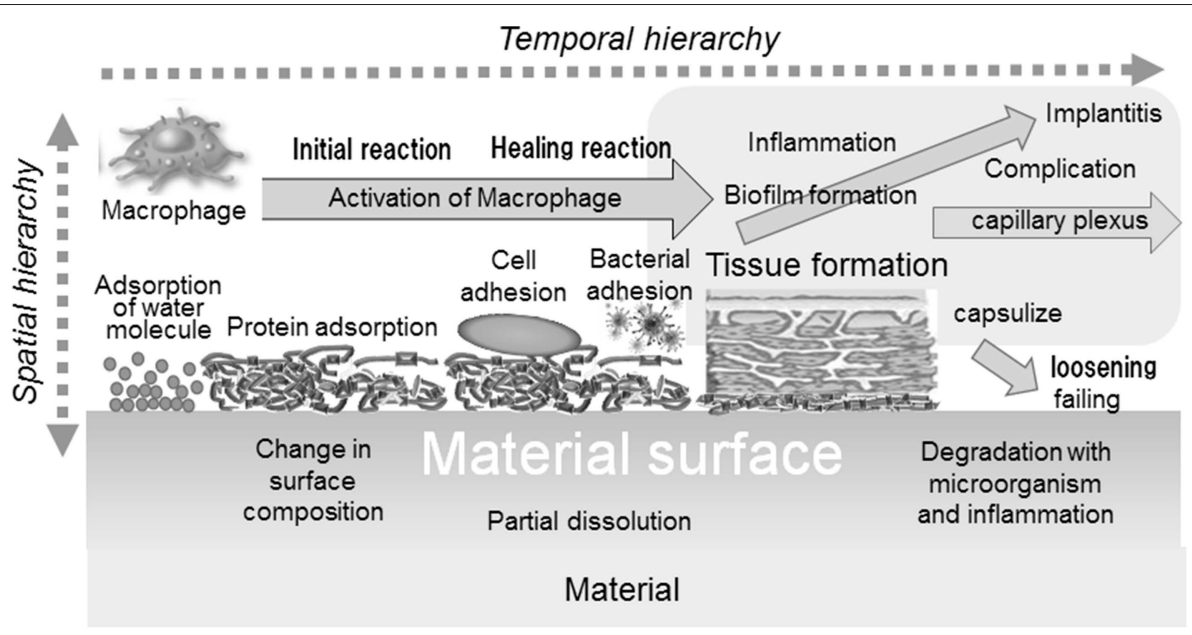

FIGURE 2 | Interfacial reactions of materials and the host body.

tissues, inflammation, etc. In addition, the reaction occurs with a temporal and spatial hierarchy, as illustrated in Figure 2.

CP Ti shows a unique property, "osseointegration," among metals. Osseointegration is defined as follows. It is the "formation of a direct interface between an implant and bone, without intervening soft tissue. No scar tissue, cartilage or ligament fibers are present between the bone and implant surface. The direct contact of bone and implant surface can be verified microscopically" (Brånemark et al., 1977). Osseointegration shows the excellent hard-tissue property of Ti. This concept, osseointegration, in dental implants generated and explosively accelerated studies on the reaction between hard tissue (bone and tooth) and $\mathrm{Ti}$, followed by studies on surface treatment.

Extensive research on the hard-tissue compatibility of Ti has been reported; it is impossible to introduce everything here, so we advise referring to a book in which it is reviewed (Brunette et al., 2001). Excellent hard-tissue compatibility of Ti was confirmed by studies on calcium phosphate formation ability in simulated body fluids; evaluation of osteoblast activity and calcification; histological and molecular-biological evaluation of Ti implanted in animals, such as bone formation, bone contacting rate, and bone bonding strength; and clinical results. The above results revealed that, when $\mathrm{Ti}$ is implanted in bone, the surrounding tissue contacts Ti in an early stage, and the bone bonding strength is large. Important factors governing hard-tissue compatibility are the adhesion and proliferation of osteogenic cells because of the surface morphology (roughness), wettability, etc. Bone formation occurs through the inflammatory response period, osteoblast induction period, and bone formation period. The surfaces of Ti implant and Ti-bone interface reaction have been characterized to explain the importance of surface morphology, wettability, and energy for osseointegration (Rupp et al., 2018; Shah et al., 2018, 2019). The surface of Ti implants stored for a long time after manufacturing becomes contaminated, and the bone conduction ability is depressed during storage (Art et al., 2009).
Bonding between metals and soft tissue is also important in abutments of dental implants, orthodontic implant anchors, transdermal devices, and screws of external fixators. In these devices, metals penetrate from the inside to the outside of tissues. Therefore, insufficient bonding of soft tissue makes the invasion of bacteria that generates inflammation possible, followed by loosening, movement, and falling out of the implant. In the case of dental implants, these events are known as peri-implantitis. Other medical devices completely implanted in tissues may be covered by fibrous tissue unless enough soft-tissue compatibility is shown. It is well-known that Ti shows good soft-tissue compatibility only in the case of complete implantation, while chemical bonding of soft tissue to $\mathrm{Ti}$ is not observed. In particular, despite the significance of the adhesion of junctional epithelium to $\mathrm{Ti}$ in dental implants, this subject is still unresolved. Bonding of junctional epithelium to $\mathrm{Ti}$ is attempted by a mechanical anchoring with rough or grooved $\mathrm{Ti}$ surfaces at present, because chemical adhesion of soft tissue to metals is difficult (Williams, 2011).

A platelet adhesion test with human blood revealed that platelets easily adhered and a fibrin network formed on $\mathrm{Ti}$ (Tanaka et al., 2009; Ratner et al., 2013). Ti may form a thrombus easily and show low blood compatibility. Probably for this reason, bare $\mathrm{Ti}$ and $\mathrm{Ti}$ alloys except Ti-Ni alloy are not used for devices contacting blood.

\section{MECHANISM OF BIOCOMPATIBILITY OF TITANIUM}

\section{Response of the Host Body}

The interface between $\mathrm{Ti}$ and bone tissue has been observed from early on at a micrometer and nanometer scale (Albrektsson and Hansson, 1986; Davies et al., 1990; Listgarten et al., 1992; Sennerby et al., 1993; Murai et al., 1996; Branemark et al., 1998; Sundell et al., 2017). Metal Ti substrate is covered by titanium oxide (a few nanometers in thickness), an amorphous layer containing proteoglycans (20-50 $\mathrm{nm}$ in thickness), a slender 
cell layer, a weakly calcified region, and bone tissue, in that order. Endeavors to observe a structure near the Ti surface have continued to elucidate the mechanism of osseointegration (Palmquist et al., 2010; Goriainov et al., 2014).

Recently, red-blood-cell and platelet interactions (Park and Davies, 2000), wettability and hydrophilicity (Gittens et al., 2014; Albrektsson and Wennerberg, 2019), increase in osteogenesis-, angiogenesis-, and neurogenesis-associated gene expression (Salvi et al., 2015), healing- and immune-modulating effect (Trindade et al., 2016), immune osteocyte-related molecular signaling mechanisms (Shah et al., 2018), and inflammationimmunological balance (Trindade et al., 2018; Albrektsson et al., 2019) have been considered as factors of osseointegration.

However, the focus of the research moved to surface treatments to accelerate bone formation and bone bonding. The reaction mechanism is usually investigated to explain the effect of the treatments. The above phenomena are caused by the surface properties of $\mathrm{Ti}$ and situational evidence; the surface properties causing the above phenomena must be understood. Properties of the Ti surface that may cause osseointegration are explained in the following subsections.

\section{Corrosion Resistance}

Ti shows excellent corrosion resistance compared with other metals (Nakayama et al., 1989; Brunette et al., 2001; Asri et al., 2017; Manam et al., 2017; Eliaz, 2019), inducing low toxicity (Figure 3). One of the reasons for the excellent biocompatibility of $\mathrm{Ti}$ is caused by the excellent corrosion resistance, while the corrosion resistance is not sufficient condition for the biocompatibility. Even the best corrosion-resistant metal, Au, is inferior in tissue compatibility. In addition, electric plating of $\mathrm{Pt}$ to $\mathrm{Ti}$ increases the corrosion resistance but depletes bone formation (Itakura et al., 1989), because a property of $\mathrm{Ti}$ is shielded, and the bone formation ability is prevented. These results reveal that hard-tissue compatibility is not induced only by the corrosion resistance. In other words, the corrosion resistance is a necessary condition but not a sufficient condition for biocompatibility; there are other factors that contribute to biocompatibility. This concept is illustrated in Figure 4.

\section{Surface Hydroxyl Groups}

The interface reaction between $\mathrm{Ti}$ and living tissue is governed by the property of surface oxide film (passive film) covering the Ti substrate. This surface oxide film forms hydroxyl groups on itself because of a reaction with moisture in the air (Boehm, 1966). These hydroxyl groups dissociate in aqueous solutions, such as body fluid, to form electric charges (Boehm, 1966, 1971; Parfitt, 1976). The electric charge depends on the $\mathrm{pH}$ of the surrounding solution, and it becomes zero at a certain $\mathrm{pH}$. This $\mathrm{pH}$ is defined as the point of zero charge (p.z.c.) (Figure 5). The p.z.c. is a unique value depending on each oxide and an indicator to show an acid or basic property. In the case of $\mathrm{TiO}_{2}$, the p.z.c. of rutile is 5.3, and that of anatase is 6.2 (Parfitt, 1976); therefore, $\mathrm{TiO}_{2}$ does not show an outstanding acid or basic property but shows almost a neutral property. The concentration of surface hydroxyl groups on $\mathrm{TiO}_{2}$ is relatively large-4.9-12.5 $\mathrm{nm}^{-2}$ (Boehm, 1971; Westall and Hohl, 1980). After immersion

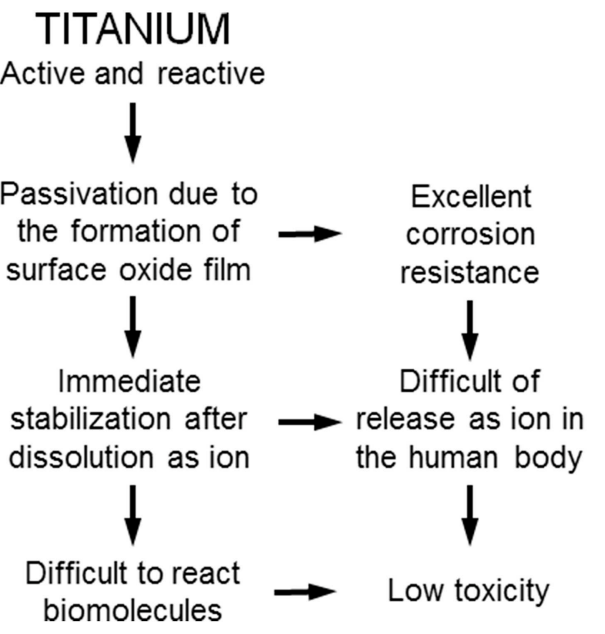

FIGURE 3 | Excellent corrosion resistance and low toxicity of titanium based on its high activity.

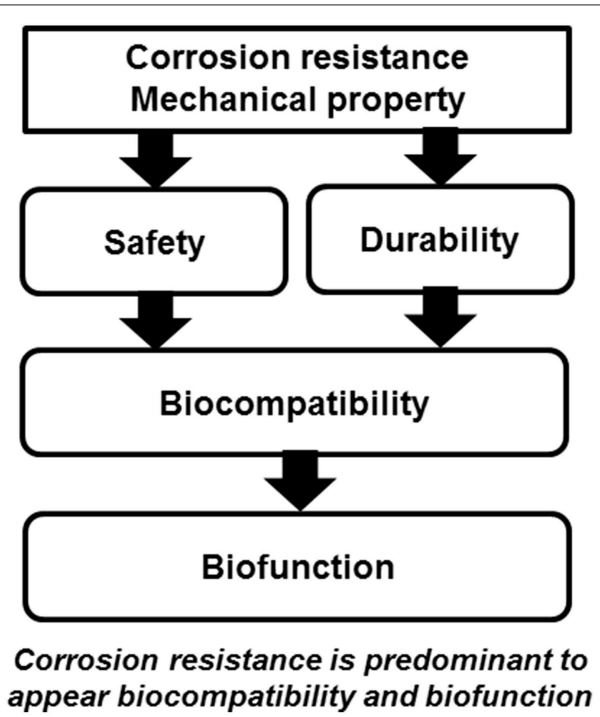

FIGURE 4 | Biocompatibility and biofunction based on corrosion resistance and mechanical property.

in aqueous solution, this concentration or wettability increases. This large concentration promotes the adsorption of proteins, such as integrin and cytokine.

\section{Protein Adsorption}

The conformation of proteins is changed by the adsorption to the metal surface, because proteins are charged objects. The electrostatic force of proteins to a metal surface is governed by the relative permittivity of the surface oxide film: the larger the relative permittivity, the smaller the electrostatic force. The relative permittivity of $\mathrm{TiO}_{2}$ is much larger than those of other oxides, 82.1, and similar to that of water (80.0) (Lide, 2006). Therefore, the conformational change of protein adsorbed on $\mathrm{TiO}_{2}$ is possibly small (Figure 6). The adsorption layer of 


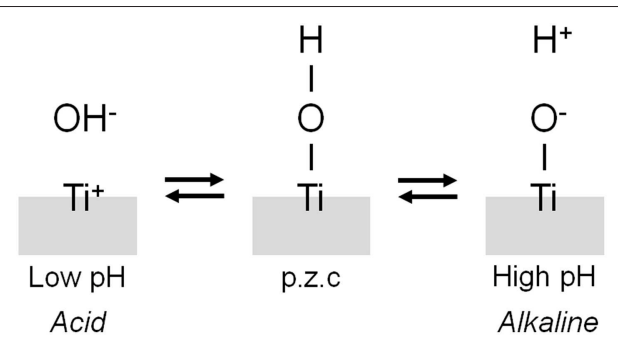

FIGURE 5 | Dissociation of surface hydroxyl group on metal.

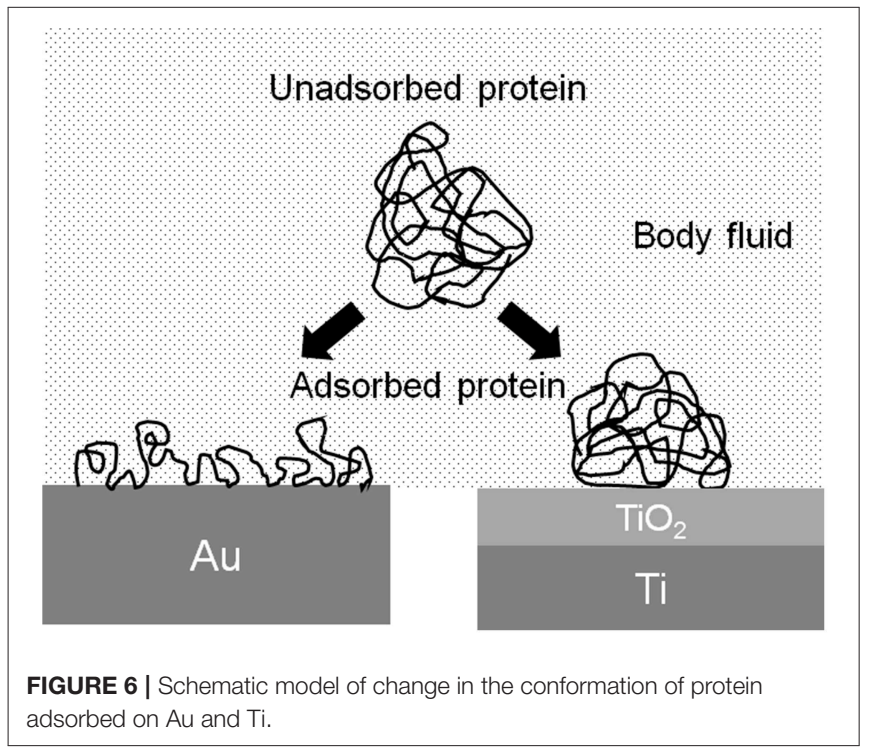

fibrinogen is thicker, but the adsorption amount is smaller on Ti than on Au in aqueous solution (Sundgren et al., 1986a). The electrostatic force on $\mathrm{Ti}$ is small, but on $\mathrm{Au}$ is large, because $\mathrm{Ti}$ is covered by $\mathrm{TiO}_{2}$ and $\mathrm{Au}$ metal exposes without surface oxide. The change in the conformation of proteins on Ti is smaller than that on Au. Proteins adsorbed on Ti are less susceptible.

\section{Formation of Calcium Phosphate}

The composition and chemical state of surface oxide film vary according to the surrounding environment; while the film is macroscopically stable. A passive film maintains a continuous process of partial dissolution and reprecipitation in the electrolyte from the microscopic viewpoint. In this sense, the surface composition is always changing according to the environment (Kelly, 1982). Ti and Ti alloys easily form calcium phosphates on themselves in a biological environment, and form sulfite and sulfide, especially under cell culture (Hanawa and Ota, 1991, 1992; Healy and Ducheyne, 1992; Serro et al., 1997; Hiromoto et al., 2004). Ti is stabilized after the formation of calcium phosphate in Hanks' solution (Tsutsumi et al., 2009). In addition, calcium and phosphorus are detected at the interface between $\mathrm{Ti}$ and bone tissue (Sundgren et al., 1986b; Esposito et al., 1999; Sundell et al., 2017). One of the reasons for the excellent hard-tissue compatibility in $\mathrm{Ti}$ is its ability to form calcium phosphate.

\section{SURFACE TREATMENT OF TITANIUM}

\section{Category}

To promote the biocompatibility of $\mathrm{Ti}$ and to add biofunction to Ti while retaining the advantage of its mechanical property, surface treatment is necessary. Surface treatment techniques for Ti continue to be reviewed (Brunette et al., 2001; Hanawa, 2009, 2017; Williams, 2011; Ratner et al., 2013; Civantos et al., 2017). Surface treatment techniques for medical applications are categorized in Figure 7, and most of them are commercially viable in the engineering field. However, some of them were originally developed for medical devices. In addition, the major purpose of surface treatments is to accelerate bone formation and bonding. Another category of surface finishing and surface treatment of implants is summarized in Figure 8. Recently, immunomodulatory applications to regenerate tissues have attracted the attention of biomaterials researchers (Lee et al., 2019). As shown in Figure 8, surface treatments and their effects are summarized in the following subsections.

\section{Control of Surface Morphology and Porous Surface}

Surface roughness influences the healing and remodeling process of tissues. Osteoblastic cells adhere well to rough metal surfaces in vitro (Rautray et al., 2011). Surface roughness also plays an important role for the differentiation of cells. For example, osteoblast accelerates collagen production and calcification on rough surfaces rather than on smooth surfaces (Keller et al., 1994). The shear bonding force increases with increasing roughness. Influence of surface topography on osseointegration has been studied (Albrektsson and Wennerberg, 2004; Wennerberg and Albrektsson, 2010; Nagasawa et al., 2016; Rupp et al., 2018). The surface roughness of a material is an important factor for bonding of tissues. Mechanical anchoring results from the ingrowth of bone tissue into pores. Even in the case where surface treatment improves the chemical composition, the effects of not only the chemical composition but also the roughness produced simultaneously by the treatment appear in most cases to accelerate bone formation and bone bonding.

The first surface treatment for biomaterials was the control of surface morphology-that is, the formation of macroscopic grooves or grids. Living tissues become ingrown in holes or pores, and mechanical anchoring is achieved. Plasma spray of Ti and hydroxyapatite (HA) on the stem of artificial joints made of Ti alloys and blast and acid etching in dental implants have been commercialized. Micro-arc oxidation (MAO) or plasma electrolytic oxidation (PEO) to form a connective porous $\mathrm{TiO}_{2}$ layer have also been commercialized in dental implants. Bone tissue grows into pores to achieve bonding. A scanning electron micrograph of porous $\mathrm{TiO}_{2}$ oxide formed on $\mathrm{Ti}$ by $\mathrm{MAO}$ is shown in Figure 9.

In the advanced morphology surface fabrication in Figure 8, an evolutional technique of surface morphological control is the formation of $\mathrm{TiO}_{2}$ nanotubes promoting cell adhesion and bone formation because of the effect of the nanometer size (Allam et al., 2008; Brammer et al., 2012; Narayanan et al., 2014; 


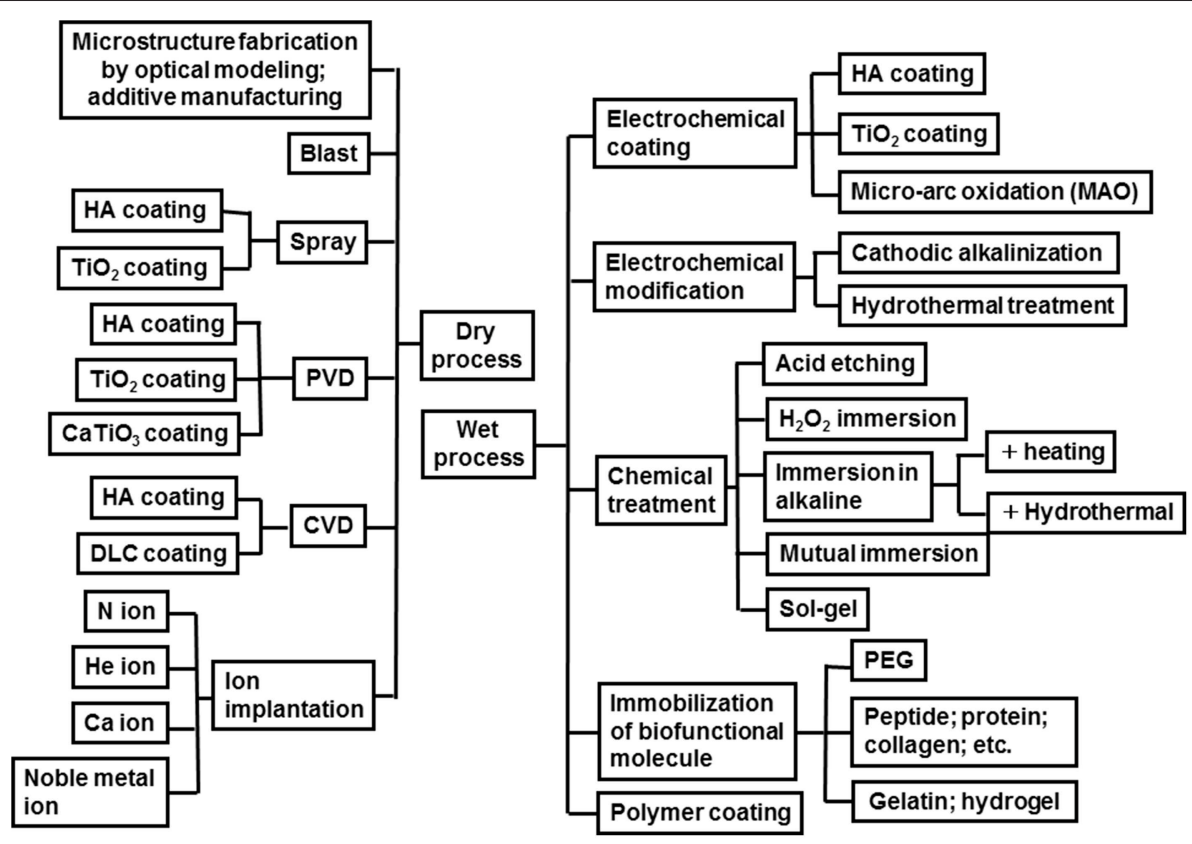

FIGURE 7 | Category of surface finishing and surface treatment of Ti to accelerate bone formation, bone bonding, soft tissue adhesion, wear resistance, antibacterial property and blood compatibility.

\begin{tabular}{|c|c|c|}
\hline $\begin{array}{l}\text { Morphological } \\
\text { surface }\end{array}$ & $\begin{array}{l}\text { Physicochemically } \\
\text { active surface }\end{array}$ & $\begin{array}{l}\text { Biochemically } \\
\text { active surface }\end{array}$ \\
\hline Groove & HA coating & Immobilization \\
\hline $\begin{array}{c}\text { Blast } \\
\text { Acid etching } \\
\text { Anodic oxidation } \\
\text { Etc. }\end{array}$ & $\begin{array}{c}\mathrm{TiO}_{2} \text { coating } \\
\text { Alkalinization } \\
\text { Etc. }\end{array}$ & $\begin{array}{c}\text { of collagen, BMP, } \\
\text { peptide, gelatine, } \\
\text { etc. }\end{array}$ \\
\hline \multicolumn{3}{|c|}{ Advanced morphological surface } \\
\hline \multicolumn{3}{|c|}{$\begin{array}{c}\mathrm{TiO}_{2} \text { nanotube } \\
\text { Cyclic nano-structure } \\
\text { Additive manufacturing } \\
\text { Laser abrasion } \\
\text { etc. }\end{array}$} \\
\hline \multicolumn{3}{|c|}{$\begin{array}{l}\text { FIGURE } \mathbf{8} \text { | Surface finishing and surface treatment of Ti to accelerate bone } \\
\text { formation and bone bonding. }\end{array}$} \\
\hline
\end{tabular}

Awad et al., 2017). On the other hand, a cyclic nanometerlevel structure accelerates bone formation (Shinonaga et al., 2014; Matsugaki et al., 2015). In addition, this structure also accelerates the adhesion and differentiation of a stem cell (Olivares-Navarrete et al., 2010; Chen et al., 2017, 2018). Bone quality is governed not only by bone density but also bone structure orientation (Ishimoto et al., 2013). Grooves oriented to a main stress vector have been designed that control the orientation of the bone structure (Noyama et al., 2013). This technique has been commercialized in a dental implant. Recently, studies to control bacterial adhesion by a cyclic structure at a micrometer level have been increasing in number (Anselme et al., 2010). Nanotopographies have been applied to form antibacterial surfaces (Orapiriyakul et al., 2018; Mas-Moruno et al., 2019).

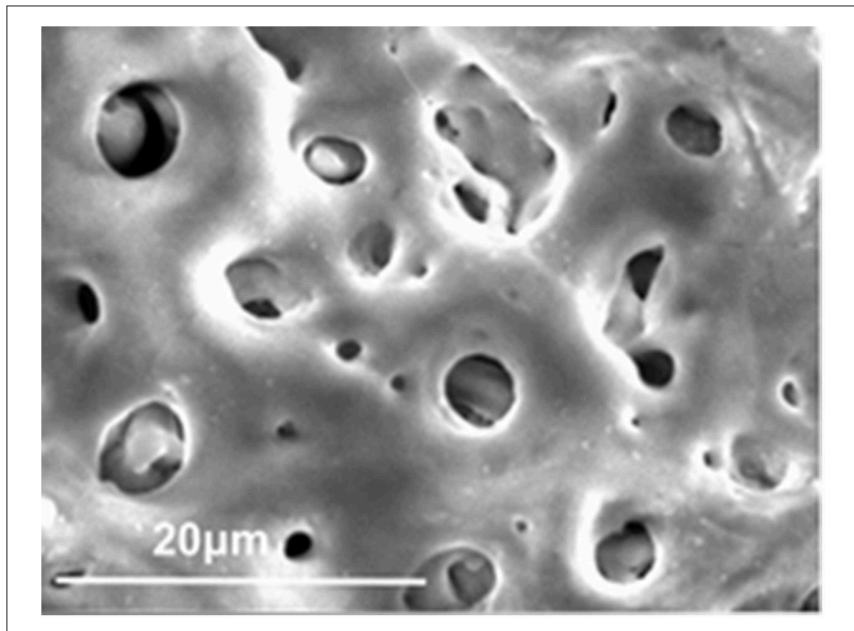

FIGURE 9 | Porous $\mathrm{TiO}_{2}$ oxide layer formed on Ti by micro-arc oxidation.

Three-dimensional additive manufacturing is an effective tool to form the above surface morphology (Wang et al., 2016). Additive-manufactured implants have been clinically applied, and effective ingrowth of bone to porous implants has been observed (Wang et al., 2017; Gao et al., 2018).

\section{Hydroxyapatite and Oxide Coatings}

To form a physicochemical active surface, $\mathrm{HA}$ is a main inorganic component of tooth and bone, so a coating of HA has been popular for accelerating bone formation and increasing resistance (Harun et al., 2018). The first technique was plasma spray (Ong and Lucas, 1994), which has been applied to various 


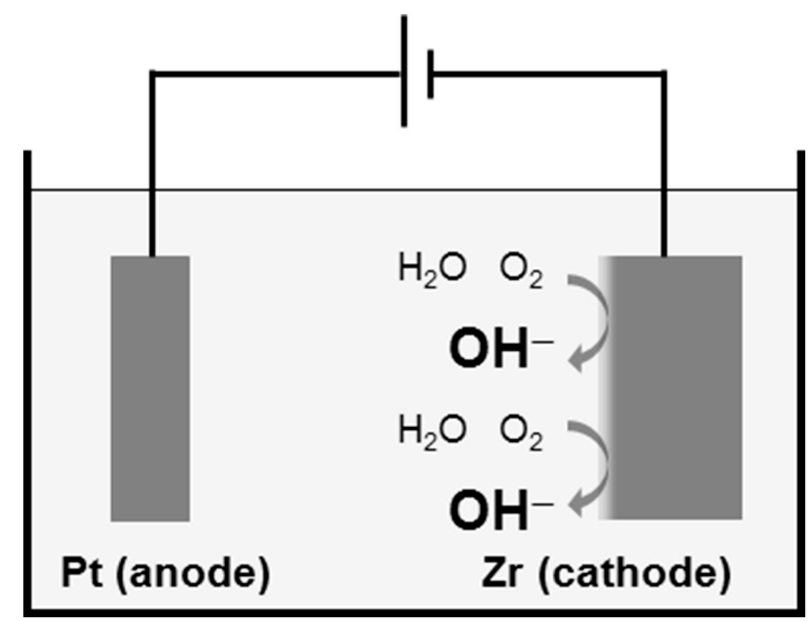

FIGURE 10 | Local alkalinization of Zr surface by cathodic polarization in a supporting electrolyte solution.

products. Thereafter, other coating techniques to form HA have been developed. Physical vapor deposition (PVD) in dry processes and electrochemical formation in wet processes are predominant, while a sol-gel technique (Li et al., 1996) and alternate immersion technique (Taguchi et al., 1999) have been developed. In addition, coatings of bioactive glass, tricalcium phosphate (Kitsugi et al., 1996), carbonate apatite (Yamaguchi et al., 2010), and octacalcium phosphate (Lin et al., 2003) with a bone formation ability larger than that of HA have been studied and developed. On the other hand, $\mathrm{TiO}_{2}$ and other oxides have been coated on Ti (Umetsu et al., 2013). The surface is simultaneously roughened with a spray coating.

\section{Surface Modification Layer Formation}

Another technique to form a physicochemical active surface has been developed. The Ti surface is activated without coatings of HA and calcium phosphate. This surface is expected to form HA in bone tissue spontaneously. The oldest technique is calcium ion implantation (Hanawa et al., 1993, 1997). On the other hand, when $\mathrm{Ti}$ is immersed in an alkaline solution, such as $\mathrm{NaOH}$ and $\mathrm{KOH}$, and heated, the surface is alkalinized, and the alkaline component is released to body fluid, followed by HA formation to form bone (Kim et al., 1996). This technique has been commercialized in an artificial hip joint. However, this technique is not effective for $\mathrm{Zr}$, which does not form calcium phosphate on itself. Thus, $\mathrm{Zr}$ is cathodically polarized, and the surface of $\mathrm{Zr}$ is locally alkalinized, as shown in Figure 10 (Tsutsumi et al., 2010).

\section{Immobilization of Biofunctional Molecules and Biomolecules}

The ideas of improvement of bone formation and of bone bonding by the immobilization of biomolecules involved in bone formation to a metal surface are logical. Such biomolecules as peptides, gelatins, and bone morphogenetic protein (BMP) are immobilized on the Ti surface (Hanawa, 2013). Immobilization of Type I collagen (Morra et al., 2011), fibronectin (Pegueroles et al., 2011), Arg-Gly-Asp (RGD) array peptide (Yamamichi et al., 2008), and BMP (Schliephake et al., 2012) is effective to promote cell spreading and bone formation. Immobilization of biomolecules has also been applied to create antibacterial surfaces (Qin et al., 2018). In the case of electrodeposition of poly(ethylene glycol) (PEG), the PEG-immobilized $\mathrm{Ti}$ inhibits protein adsorption, platelet adhesion (Tanaka et al., 2010a), and bacteria (Tanaka et al., 2010b).

The idea that the bone formation of a material's surface becomes active by the immobilization of biomolecules in bone formation is reasonable, and many studies have been conducted. However, to popularize the immobilization of biofunctional molecules widely, it is necessary to ensure the safety, maintenance of quality during storage, and dryconditioned durability of the immobilized layer. It is difficult for manufacturers to commercialize this technique unless they see value in commercialization. There are many problems with commercializing the immobilized materials, although it is easy to show good results in basic research.

\section{Cleaning and Hydrophilic Treatment}

Surface contamination prevents bone formation and bone bonding in dental implants (Ueno et al., 2012). Instruments for optical activation treatments, such as ultraviolet irradiation and plasma irradiation, are available. Surface contamination is removed, and surface hydroxyl groups appear on the Ti surface in these optical activation treatments. The bone formation ability of a material is related to its wettability (Yamamoto et al., 2012). Surface characteristics of Ti implant have been reviewed elsewhere (Rupp et al., 2018).

\section{SUMMARY AND PERSPECTIVE}

$\mathrm{Ti}$ is the most biocompatible material among metals. Unfortunately, the underlying mechanism still has not been elucidated completely. Research and development have been focused on surface treatments to improve bone formation and bone bonding, leaving behind the understanding of the mechanism. However, the mechanism of the biocompatibility of $\mathrm{Ti}$ is gradually being understood with the research on surfacetreated materials. Ti is the most bioactive material among metals, but it is less active than bioactive ceramics. The elucidation of the relevant mechanism can accelerate the development of optimal surfaces. The surface treatment techniques introduced in this review make it possible to apply metals to a scaffold in regenerative medicine or tissue engineering.

\section{AUTHOR CONTRIBUTIONS}

The author confirms being the sole contributor of this work and has approved it for publication.

\section{ACKNOWLEDGMENTS}

This work was supported by Creation of Life Innovation Materials for Interdisciplinary and International Researcher Development Project and Biable Materials Project, Ministry of Education, Culture, Sports, Science and Technology (MEXT), Japan. 


\section{REFERENCES}

Ahmed, M., Wexler, D., Castillas, G., Savvakin, D. G., and Pereloma, E. V. (2016). Strain rate dependence of deformation-induced transformation and twinning in a metastable titanium alloy. Acta Mater. 104, 190-200. doi: 10.1016/j.actamat.2015.11.026

Albrektsson, T., and Hansson, H. A. (1986). An ultrastructural characterization of the interface between bone and sputtered titanium or stainless steel surfaces. Biomaterials 7, 201-205. doi: 10.1016/0142-9612(86) 90103-1

Albrektsson, T., Jemt, T., Molne, J., Tengvall, P., and Wennerberg, A. (2019). On inflammation-immunological balance theory-A critical apprehension of disease concepts around implants: mucositis and marginal bone loss may represent normal conditions and not necessarily a state of disease. Clin. Implant. Dent. Relat. Res. 21, 183-189. doi: 10.1111/cid.12711

Albrektsson, T., and Wennerberg, A. (2004). Oral implant surfaces: part 1 - review focusing on topographic and chemical properties of different surfaces and in vivo responses to them. Int. J. Prosthodont. 17, 536-543.

Albrektsson, T., and Wennerberg, A. (2019). On osseointegration in relation to implant surfaces. Clin. Implant. Dent. Relat. Res. 21, 4-7. doi: 10.1111/cid.12742

Allam, N. K., Shankar, K., and Grimes, C. A. (2008). A general method for the anodic formation of crystalline metal oxide nanotube arrays without the use of thermal annealing. Adv. Mater. 20, 3942-3946. doi: 10.1002/adma.200800815

Alves, V. A., Reis, R. Q., Santos, I. C. B., Souza, D. G., Goncalves, T. D., Pereira-da-Silva, M. A., et al. (2009). In situ impedance spectroscopy study of the electrochemical corrosion of $\mathrm{Ti}$ and $\mathrm{Ti}-6 \mathrm{Al}-4 \mathrm{~V}$ in simulated body fluid at 25 degrees C and 37 degrees C. Corros. Sci. 51, 2473-2482. doi: 10.1016/j.corsci.2009.06.035

Anon (1994). “Ti-6Al-2Nb-lTa-0.8Mo(Ti-6211)," in Materials Properties Handbook, eds R. Boyer, G. Welsch, and E. W. Collings (Phoenix, AZ: ASM International), 321-336.

Anselme, K., Davidson, P., Popa, A. M., Giazzon, M., Liley, M., and Ploux, I. (2010). The interaction of cells and bacteria with surfaces structured at the nanometre scale. Acta Biomater. 6, 3824-3846. doi: 10.1016/j.actbio.2010.04.001

Art, W., Hori, N., Takeuchi, M., Ouyang, J., Yang, Y., Anpo, M., et al. (2009). Time- dependent degradation of titanium osteoconductivity: an implication of biological aging of implant materials. Biomaterials 30, 5352-5363. doi: 10.1016/j.biomaterials.2009.06.040

Asri, R. I. M., Harun, W. S. W., Samykano, M., Lah, N. A. C., Ghani, S. A. C., Tarlochan, F., et al. (2017). Corrosion and surface modification on biocompatible metals: a review. Mater. Sci. Eng. C 77, 1261-1274. doi: 10.1016/j.msec.2017.04.102

Awad, N. K., Edwards, S. L., and Morsi, Y. S. (2017). A review of $\mathrm{TiO}_{2}$ NTs on Ti metal: electrochemical synthesis, functionalization and potential use as bone implants. Mater. Sci. Eng. C 76, 1401-1412. doi: 10.1016/j.msec.2017.02.150

Beder, O. E., Stevenson, J. K., and Jones, T. W. (1957). A further investigation of the surgical application of titanium metal in dogs. Surgery 41, 1012-1015.

Boehm, H. P. (1966). Functional groups on the surfaces of solids. Angew. Chem. 5, 533-544. doi: 10.1002/anie.196605331

Boehm, H. P. (1971). Acidic and basic properties of hydroxylated metal oxide surfaces. Discuss. Faraday Soc. 52, 264-289. doi: 10.1039/DF9715200264

Bothe, R. T., Beaton, L. E., and Davenport, H. A. (1940). Reaction of bone to multiple metallic implants. Surg. Gynec. Obsbtet. 71, 598-602.

Brånemark, P.-I., Hansson, B. O., Adell, R., Breine, U., Lindström, J., Hallén, O., et al. (1977). Osseointegrated implants in the treatment of the edentulous jaw. Experience from a 10-year period. Scand. J. Plastic Reconstruct. Surg. Hand Surg. 11(Suppl. 16), 1-132.

Brammer, K. S., Frandsen, C. J., and Jin, S. (2012). $\mathrm{TiO}_{2}$ nanotubes for bone regeneration. Trend. Biotechnol. 30, 315-322. doi: 10.1016/j.tibtech.2012.02.005

Branemark, R., Ohrnell, L. O., Skalak, R., Carlsson, L., and Brånemark, P.-I. (1998). Biomechanical characterization of osseointegration: an experimental in vivo investigation in the beagle dog. J. Orthop. Res. 16, 61-69. doi: 10.1002/jor.1100160111

Brozek, C., Sun, F., Vermaut, P., Millet, Y., Lenain, A., Embury, D., et al. (2016). A $\beta$-type alloy with extra high strain-hardening rate: design and mechanical properties. Scr. Mater. 114, 60-64. doi: 10.1016/j-scriptamat.2015.11.020

Brunette, D. M., Tenvall, P., Textor, M., and Thomsen, P. (2001). Titanium in Medicine. Berlin: Springer.
Buehler, W. J., Gilfrich, J. W., and Wiley, R. C. (1963). Effects of low-temperature phase changes on the mechanical properties of alloys near composition TiNi. J. Appl. Phys. 34, 1475-1477. doi: 10.1063/1.1729603

Chen, P., Aso, T., Sasaki, R., Ashida, M., Tsutsumi, Y., Doi, H., et al. (2018). Adhesion and differentiation behaviors of mesenchymal stem cells on titanium with micrometer and nanometer-scale grid patterns produced by femtosecond laser irradiation, J. Biomed. Mater. Res. Part A 106, 2736-2743. doi: 10.1002/jbm.a.36503

Chen, P., Aso, T., Sasaki, R., Tsutsumi, Y., Ashida, M., Doi, H., et al. (2017). Micron/submicron hybrid topography of titanium surfaces influences adhesion and differentiation behaviors of the mesenchymal stem cells. J. Biomed. Nanotechnol. 13, 324-336. doi: 10.1166/jbn.2017.2335

Civantos, A., Martinez-Campos, E., Ramos, V., Elvira, C., Gallardo, A., and Abarrategi, A. (2017). Titanium coatings and surface modifications: toward clinically useful bioactive implants. ACS Biomater. 3, 1245-1261. doi: 10.1021/acsbiomaterials.6b00604

Davies, J. E., Lowenberg, B., and Shiga, A. (1990). The bone titanium interface in vitro. J. Biomed. Mater. Res. 24, 1289-1306. doi: 10.1002/jbm.820241003

Eliaz, N. (2019). Corrosion of metallic biomaterials: a review. Materials 12:407. doi: $10.3390 / \mathrm{ma} 12030407$

Esposito, M., Lausmaa, J., Hirsch, J. M., and Thomsen, P. (1999). Surface analysis of failed oral titanium implants. J. Biomed. Mater. Res. 48, 559-568.

Fanning, J. C. (1996). "Properties and processing of a new metastable beta titanium alloy for surgical implant applications," in Titanium'95: Science and Technology, eds P. A. Blenkinsop, W. J. Evans, and H. Flower (Cambridge: The University Press), 1800-1807.

Fukushima, A., Mayanagi, G., Nakajo, K., Sasaki, K., and Takahashi, N. (2014) Microbiologically induced corrosive properties of the titanium surface. J. Dent. Res. 93, 525-529. doi: 10.1177/0022034514524782

Gao, C., Wang, C., Jin, H., Wang, Z., Li, Z., Shi, C., et al. (2018) Additive manufacturing technique-designed metallic porous implants for clinical application in orthopedics. RSC $A d v$. 8:25210. doi: 10.1039/c8ra $04815 \mathrm{k}$

Gefen, A. (2002). Computational simulations of stress shielding and bone resorption around existing and computer-designed orthopaedic screws. Med. Bio. Eng. Comp. 40, 311-322. doi: 10.1007/BF02344213

Gittens, R. A., Scheideler, L., Rupp, F., Hyzy, S. L., Geis-Gerstorfer, J., Schwartz, Z., et al. (2014). A review on the wettability of dental implant surfaces II: biological and clinical aspects. Acta Biomater. 10, 2907-2918. doi: 10.1016/j.actbio.2014.03.032

Goriainov, V., Cook, R., Latham, J. M., Dunlop, D. G., and Oreffo, R. O. C. (2014). Bone and metal: an orthopaedic perspective on osseointegration of metals. Acta Biomater. 10, 4043-4057. doi: 10.1016/j.actbio.2014. 06.004

Hanawa, T. (2009). An overview of biofunctionalisation of metals in Japan. J. $R$. Soc. Interface 6, S361-S369. doi: 10.1098/rsif.2008.0427.focus

Hanawa, T. (2013). "Metal-polymer composite biomaterial," Polymeric Biomaterials: Structure and Function, Volume 1, eds S. Dumitriu and V. Popa (Boca Raton, FL: CRC Press), 343.

Hanawa, T. (2017). "Transition of surface modification of titanium for medical and dental use," Titanium in Medical and Dental Applications, eds F. H. Froes and M. Qian (Cambridge, UK: Woodhead Publishing), 95-114.

Hanawa, T., Kamiura, Y., Yamamoto, S., Kohgo, T., Amemiya, A., Ukai, H., et al. (1997). Early bone formation around calcium-ion-implanted titanium inserted into rat tibia. J. Biomed. Mater. Res. 36, 131-136.

Hanawa, T., and Ota, M. (1991). Calcium phosphate naturally formed on titanium in electrolyte solution. Biomaterials 12, 767-774. doi: 10.1016/0142-9612(91)90028-9

Hanawa, T., and Ota, M. (1992). Characterization of surface-film formed on titanium in electrolyte using XPS. Appl. Surf. Sci. 55, 269-276. doi: 10.1016/0169-4332(92)90178-Z

Hanawa, T., Ukai, H., and Murakami, K. (1993). X-ray photoelectron spectroscopy of calcium-ion-implanted titanium. J. Electron Spectros. Relat. Phenomena 63, 347-354. doi: 10.1016/0368-2048(93)80032-H

Harun, W. S. W., Asri, R. I. M., Alias, J., Zulkifli, F. H., Kadirgama, K., Ghani, S. A. C., et al. (2018). A comprehensive review of hydroxyapatitebased coatings adhesion on metallic biomaterials. Ceram. Int. 44, 1250-1268. doi: 10.1016/j.ceramint.2017.10.162 
Healy, K. E., and Ducheyne, P. (1992). The mechanisms of passive dissolution of titanium in a model physiological environment. J. Biomed. Mater. Res. 26, 319-338. doi: 10.1002/jbm.820260305

Heintz, C., Riepe, G., Birken, L., Kaiser, E., Chakfe, N., Morlock, M., et al. (2001). Corroded nitinol wires in explanted aortic endografts: an important mechanism of failure? J. Endovasc. Ther. 8, 248-253. doi: $10.1177 / 152660280100800303$

Hiromoto, S., Hanawa, T., and Asami, K. (2004). Composition of surface oxide film of titanium with culturing murine fibroblasts L929. Biomaterials 25, 979-986. doi: $10.1016 / \mathrm{S} 0142-9612(03) 00620-3$

Ishimoto, T., Nakano, T., Umakosh, Y., Yamamoto, M., and Tabata, Y. (2013). Degree of biological apatite c-axis orientation rather than bone mineral density controls mechanical function in bone regenerated using recombinant bone morphogenetic protein-2. J. Bone Miner. Res. 28, 1170-1179. doi: $10.1002 / j b m r .1825$

Itakura, Y., Tajima, T., Ohoke, S., Matsuzawa, J., Sudo, H., and Yamamoto, S. (1989). Osteocompatibility of platinum-plated titanium assessed in vitro. Biomaterials 10, 489-493. doi: 10.1016/0142-9612(89)90091-4

Keller, J. C., Stanford, C. M., Wightman, J. P., Draughn, R. A., and Zaharias, R. (1994). Characterizations of titanium implant surfaces. III. J. Biomed. Mater. Res. 28:939. doi: $10.1002 / \mathrm{jbm} .820280813$

Kelly, E. J. (1982). Electrochemical behavior of titanium. Mod. Aspect. Electrochem. $14,319-424$.

Kim, H. M., Miyaji, F., Kokubo, T., and Nakamura, T. (1996). Preparation of bioactive $\mathrm{Ti}$ and its alloys via simple chemical surface treatment. J. Biomed. Mater. Res. 32, 409-417.

Kitsugi, T., Nakamura, T., Oka, M., Senaha, Y., Goto, T., and Shibuya, T. (1996). Bone-bonding behavior of plasma-sprayed coatings of Bioglass(R), AW-glass ceramic, and tricalcium phosphate on titanium alloy. J. Biomed. Mater. Res. $30,261-269$.

Kroll, W. J. (1940). The production of ductile titanium. Trans. Electrochem. Soc. 78, 35-47. doi: 10.1149/1.3071290

Kuroda, D., Niinomi, M., Morinaga, M., Kato, Y. T., and Yashiro, T. (1988). Design and mechanical properties of new $\beta$ type titanium alloys for implant materials. Mater. Sci. Eng. A 243, 244-249. doi: 10.1016/S0921-5093(97)00808-3

Lai, M. J., Li, T., and Raabe, D. (2018). $\omega$ phase acts as a switch between dislocation channeling and joint twinning- and transformation-induced plasticity in a metastable $\beta$ titanium alloy. Acta Mater. 151, 67-77. doi: 10.1016/j.actamat.2018.03.053

Lee, J., Byun, H., Perikamana, S. K. M., Lee, S., and Shin, H. (2019). Current advances in immunolomodulatory biomaterials for bone regeneration. $A d v$. Healthcare Mater. 8:1801106. doi: 10.1002/adhm.201801106

Leventhal, G. S. (1951). Titanium, a metal for surgery. J. Bone Joint Surg. Am. 33A, 473-474. doi: 10.2106/00004623-195133020-00021

Li, P., deGroot, K., and Kokubo, T. (1996). Bioactive $\mathrm{Ca}_{10}\left(\mathrm{PO}_{4}\right)_{6}(\mathrm{OH})_{2}-\mathrm{TiO}_{2}$ composite coating prepared by sol-gel process. J. Sol Gel Sci. Technol. 7, 27-34. doi: 10.1007/BF00401880

Li, Y., Wong, C., Xiong, J., Hodgson, P., and Wen, C. (2010). Cytotoxicity of titanium and titanium alloying elements. J. Dent. Res. 89, 493-497. doi: $10.1177 / 0022034510363675$

Lide, D. R. (ed.). (2006). CRC Handbook of Chemistry and Physics, 87th Edn. Boca Raton, FL: CRC Press.

Lin, S. J., LeGeros, R. Z., and LeGeros, J. P. (2003). Adherent octacalcium phosphate coating on titanium alloy using modulated electrochemical deposition method, J. Biomed. Mater. Res. 66A, 819-828. doi: 10.1002/jbm.a.10072

Listgarten, M. A., Buser, D., Steinemann, S. G., Donath, K., Lang, N. P., and Weber, H. P. (1992). Light and transmission electron microscopy of the intact interfaces between non-submerged titanium-coated epoxy resin implants and bone or gingiva. J. Dent. Res. 71, 364-371. doi: 10.1177/00220345920710020401

Manam, N. S., Harum, W. S. W., Shri, D. N. A., Ghani, S. A. C., Kurniawan, T., and Ismail, M. H. (2017). Study of corrosion in biocompatible metals for implants: a review. J. Alloy. Compound. 701, 698-715. doi: 10.1016/j.allcom.2017.01.196

Marteleur, M., Sun, F., Gloriant, T., Vermaut, P., Jacques, P. J., and Prima, F. (2012). On the design of new n-metastable titanium alloys with improved work hardening rate thanks to simultaneous TRIP and TWIP effects. Scr. Mater. 66, 794-752. doi: 10.1016/j-scriptamat.2012.01.049
Mas-Moruno, C., Su, B., and Dalby, M. J. (2019). Multifunctional coatings and nanotopographies: toward cell instructive and antibacterial implants. Adv. Healthcare Mater. 8:1801103. doi: 10.1002/adhm.201801103

Matsuda,. Y., Nakamura, T., Ido, K., Oka, M., Okumura, H., and Matsushita, T. (1997). Femoral component made of Ti-15Mo-5Zr-3Al alloy in total hip arthroplasty. J. Orthop. Sci. 2, 166-170.

Matsugaki, A., Aramoto, G., Ninomiya, T., Sawada, H., Hata, S., and Nakano, T. (2015). Abnormal arrangement of a collagen/apatite extracellular matrix orthogonal to osteoblast alignment is constructed by a nanoscale periodic surface structure. Biomaterials 37, 134-143. doi: 10.1016/j.biomaterials.2014.10.025

Miura, I., and Ida, K. (Eds.). (1988). Titanium in Dentistry. Tokyo: Quintessence.

Morra, M., Cassinelli, C., Cascardo, G., Bollati, D., and Rodriguezy Baena, R. (2011). Collagen I-coated titanium surfaces: mesenchymal cell adhesion and in vivo evaluation in trabecular bone implants. J. Biomed. Mater. Res. 96A, 449-458. doi: 10.1002/jbm.a.30783

Murai, K., Takeshita, F., Ayukawa, Y., Kiyoshima, T., Suetsugu, T., and Tanaka, T. (1996). Light and electron microscopic studies of bone-titanium interface in the tibiae of young and mature rats. J. Biomed. Mater. Res. 30, 523-533.

Nagasawa, M., Cooper, L. F., Ogino, Y., Mendonca, D., Liang, R., Yang, S., et al. (2016). Topography influences adherent cell regulation of osteoclastogenesis. J. Dent. Res. 95, 319-326. doi: 10.1177/0022034515616760

Nakagawa, M., Matsuya, S., Shiraishi, T., and Ohta, M. (1999). Effect of fluoride concentration and $\mathrm{pH}$ on corrosion behavior of titanium for dental use. J. Dent. Res. 78, 1568-1572. doi: 10.1177/00220345990780091201

Nakayama, Y., Yamamuro, T., Kotoura, Y., and Oka, M. (1989). In vivo measurement of anodic polarization of orthopaedic implant alloys: comparative study of in vivo and in vitro experiments. Biomaterials 10 , 420-414. doi: 10.1016/0142-9612(89)90134-8

Narayanan, R., Kwon, T. W., and Kim, K. H. (2014). $\mathrm{TiO}_{2}$ nanotubes from stirred glycerol/ $/ \mathrm{NH}_{4} \mathrm{~F}$ electrolyte: roughness, wetting behavior and adhesion for implant applications. Mater. Chem. Phys. 117, 460-464. doi: 10.1016/j.matchemphys.2009.06.023

Niinomi, M. (2019). Design and development of metallic biomaterials with biological and mechanical biocompatibility. J. Biomed. Mater. Res. Part A 107A, 944-954. doi: 10.1022/jbm.a.36667

Noyama, Y., Nakano, T., Ishimoto, T., Sakai, T., and Yoshikawa, H. (2013). Design and optimization of the oriented groove on the hip implant surface to promote bone microstructure integrity. Bone 52, 659-667. doi: 10.1016/j.bone.2012.11.005

Okazaki, Y. (2001). A New Ti-15Zr-4Nb-4Ta alloy for medical applications. Curr. Opin. Solid State Mater. Sci. 5, 45-53. doi: 10.1016/S1359-0286(00)00025-5

Olivares-Navarrete, R., Hyzy, S. L., Hutton, D. L., Erdman, C. P., Wieland, M., Boyan, B. D., et al. (2010). Direct and indirect effects of microstructured titanium substrates on the induction of mesenchymal stem cell differentiation towards the osteoblast lineage. Biomaterials 31, 2728-2735. doi: 10.1016/j.biomaterials.2009.12.029

Ong, J. L., and Lucas, L. C. (1994). Postdeposition heat-treatments for ionbeam sputter-deposited calcium-phosphate coatings. Biomaterials 15, 337-341. doi: 10.1016/0142-9612(94)90245-3

Orapiriyakul, W., Young, P. S., Damiati, L., and Tsimbouri, P. M. (2018). Antibacterial surface modification of titanium implants in orthopaedics. J. Tissue Eng. 9, 1-16. doi: 10.1177/2041731418789838

Ozaki, T., Matsumoto, H., Watanabe, S., and Hanada, S. (2004). Beta Ti alloys with low Young's modulus. Mater. Trans. 45, 2776-2779. doi: 10.2320/matertrans.45.2776

Palmquist, A., Omar, O. M., Esposito, M., Lausmaa, J., and Thomsen, P. (2010). Titanium oral implants: surface characteristics, interface biology and clinical outcome. J. R. Soc. Interface 7, S515-S527. doi: 10.1098/rsif.2010.0118.focus

Parfitt, G. D. (1976). The surface of titanium dioxide. Prog. Surf. Membr. Sci. $11,181-226$.

Park, J. Y., and Davies, J. E. (2000). Red blood cell and platelet interactions with titanium implant surfaces. Clin. Oral Implant. Res. 11, 530-539. doi: 10.1034/j.1600-0501.2000.011006530.x

Pegueroles, M., Aguirre, A., Engel, E., Pavon, G., Gil, F. J., Planell, J. A., et al. (2011). Effect of blasting treatment and Fn coating on MG63 adhesion and 
differentiation on titanium: a gene expression study using real-time RT-PCR. J. Mater. Sci. Mater. Med. 22, 617-627. doi: 10.1007/s10856-011-4229-3

Pillar, R. M., and Weatherly, G. C. (1982). "Development in implant alloys" in Clinical Reviews in Biocompatibility, Vol. 1, ed D. F. Williams (Boca Raton, FL: CRC Press), 371-473.

Qin, S., Xu, K., Nie, B., Ji, F., and Zhang, H. (2018). Approaches based on passive and active antibacterial coating on titanium to achieve antibacterial activity. J. Biomed. Mater. Res. Part A 106A, 2531-2539. doi: 10.1002/jbm.a. 36413

Rao, V. B., and Houska, C. R. (1979). Kinetics of the phase-transformation in a Ti-15Mo-5Zr-3Al alloy as studied by X-ray-diffraction. Metal. Trans. A 10, 355-358. doi: 10.1007/BF02658345

Ratner, B. D., Hoffman, A. S., Schoen, F. J., and Lemons, J. E. (Eds.). (2013). Biomaterials Science-An Introduction to Materials in Medicine, 3rd Edn. Oxford, UK: Academic Press.

Rautray, T. R., Narayanan, R., Kwon, T. Y., and Kim, K. H. (2011). Ion implantation of titanium based biomaterials. Prog. Mater. Sci. 56, 1137-1177. doi: 10.1016/j.pmatsci. 2011.03.002

Rupp, F., Liang, L., Geis-Gerstorfer, J., Scheideler, L., and Hüttig, F. (2018). Surface characteristics of dental implants: a review. Dent. Mater. 34, 40-57. doi: 10.1016/.jental.2017.09.007

Salvi, G. E., Bosshardt, D. D., Lang, N. P., Abrahamsson, I., Berglundh, T., Lindhe, J., et al. (2015). Temporal sequence of hard and soft tissue healing around titanium dental implants. Periodontology 68, 135-152. doi: 10.1111/prd.12054

Sanderson, L., Ryan, W., and Turner, P. G. (1992). Complications of metalwork removal injury. Injury 23, 29-30. doi: 10.1016/0020-1383(92)90121-8

Scheinert, D., Scheinert, S., Sax, J., Piorkowski, C., Braunlich, S., Ulrich, M., et al. (2005). Prevalence and clinical impact of stent fractures after femoropopliteal stenting. J. Am. Coll. Cardiol. 45, 312-315. doi: 10.1016/j.jacc.2004.11.026

Schliephake, H., Boetel, C., Foerster, A., Schwenzer, B., and Reichert, J. (2012). Effect of oligonucleotide mediated immobilization of bone morphogenic proteins on titanium surfaces. Biomaterials 33, 1315-1322. doi: 10.1016/j.biomaterials.2011.10.027

Semlitsch, M., and Staub, F. H. W. (1985). Titanium-aluminium-niobium alloy development for biocompatible, high strength surgical implants. Biomed. Tech. $30,334-339$.

Sennerby, L., Thomsen, P., and Ericson, L. E. (1993). Early tissue response to titanium implants inserted in rabbit cortical bone. J. Mater. Sci. Mater. Med. 4, 494-502. doi: 10.1007/BF00120129

Serro, A. P., Fernandes, A. C., Saramago, B., Lima, J., and Barbosa, M. A. (1997). Apatite desorption on titanium surfaces - the role of albumin adsorption. Biomaterials 18, 963-968. doi: 10.1016/S0142-9612(97)00031-8

Shah, F. A., Thomsen, P., and Palmquist, A. (2018). A review of the impact of implant biomaterials on osteocytes. J. Dent. Res. 97, 977-986. doi: $10.1177 / 0022034518778033$

Shah, F. A., Thomsen, P., and Palmquist, A. (2019). Osseointegration and current interpretations of bone-implant interface. Acta Biomater. 84, 1-15. doi: 10.1016/j.actbio.2018.11.018

Shinohara, Y., Tahara, M., Inamura, T., Miyazaki, S., and Hosoda, H. (2015). Effect of annealing temperature on microstructure and superelastic properties of Ti-Au-Cr-Zr alloy. Mater. Trans. 56, 404-409. doi: 10.2320/matertrans. M2014439

Shinonaga, T., Tsukamoto, M., Nagai, A., Yamashiata, K., Hanawa, T., Matsushita, N., et al. (2014). Cell spreading on titanium dioxide film formed and modified with aerosol beam and femtosecond laser. Appl. Surf. Sci. 288, 649-653. doi: 10.1016/j.apsusc.2013.10.090

Sundell, G., Dahlin, C., Andersson, M., and Thuvander, M. (2017). The boneimplant interface of dental implants in humans on the atomic scale. Acta Biomater. 48, 445-450. doi: 10.1016/j.actbio.2016.11.044

Sundgren, J.-E., Bodö, P., Ivarsson, B., and Lundström, I. (1986a). Adsorption of fibrinogen on titanium and gold surfaces studied by esca and ellipsometry. J. Colloid Interface Sci. 113, 530-543.

Sundgren, J. E., Bodo, P., and Lundstrom, I. (1986b). Auger electron spectroscopic studies of the interface between human tissue and implants of titanium and stainless steel. J. Colloid Interface Sci. 110, 9-20. doi: 10.1016/0021-9797(86)90348-6

Taguchi, T., Kishida, A., and Akashi, M. (1999). Apatite formation on/in hydrogel matrices using an alternate soaking process (III): effect of physico-chemical factors on apatite formation on/in poly(vinyl alcohol) hydrogel matrices. J. Biomater. Sci. Polymer Ed. 10, 795-804. doi: 10.1163/156856299 X00883

Tanaka, Y., Kurashima, K., Saito, H., Nagai, A., Tsutsumi, Y., Doi, H., et al. (2009). In vitro short term platelet adhesion on various metals. J. Artf. Org. 12, 182-186. doi: 10.1007/s10047-009-0468-1

Tanaka, Y., Matin, K., Gyo, M., Okada, A., Tsutsumi, Y., Doi, H., et al. (2010b). Effects of electrodeposited poly(ethylene glycol) on biofilm adherence to titanium. J. Biomed. Mater. Res. Part A 95A, 1105-1113. doi: $10.1002 /$ jbm.a.32932

Tanaka, Y., Matsuo, Y., Komiya, T., Tsutsumi, Y., Doi, H., Yoneyama, T., et al. (2010a). Characterization of the spatial immobilization manner of poly(ethylene glycol) to a titanium surface with immersion and electrodeposition and its effects on platelet adhesion. J. Biomed. Mater. Res. Part A 92A, 350-358. doi: 10.1002/jbm.a.32375

Trindade, R., Albrektsson, T., Galli, S., Prgomet, Z., Tengvall, P., and Wennerberg, A. (2018). Osseointegration and foreign body reaction: titanium implants activate the immune system and suppress bone resorption during the first 4 weeks after implantation. Clin. Implant Dent. Relat. Res. 20, 82-91. doi: $10.1111 /$ cid. 12578

Trindade, R., Albrektsson, T., Tengvall, P., and Wennerberg, A. (2016). Foreign body reaction to biomaterials: on mechanisms for buildup and breakdown of osseointegration. Clin. Implant Dent. Relat. Res. 18, 192-203. doi: $10.1111 /$ cid.12274

Tsutsumi, Y., Nishimura, D., Doi, H., Nomura, N., and Hanawa, T. (2009). Calcium phosphate formation on titanium and zirconium and its application to medical devices. Mater. Sci. Eng. C29, 1702-1708. doi: 10.4303/bda/D110119

Tsutsumi, Y., Nishimura, D., Doi, H., Nomura, N., and Hanawa, T. (2010). Cathodic alkaline treatment of zirconium to give the ability to form calcium phosphate. Acta Biomater. 6, 4161-4166. doi: 10.1016/j.actbio.2010.05.010

Ueno, T., Takeuchi, M., Hori, N., Iwasa, F., Minamikawa, H., Igarashi, Y., et al. (2012). Gamma ray treatment enhances bioactivity and osseointegration capability of titanium. J. Biomed. Mater. Res. Appl. Biomater. 100B, 2279-2287. doi: 10.1002/jbm.b.32799

Umetsu, N., Sado, S., Ueda, K., Tajima, K., and Narushima, T. (2013). Formation of anatase on commercially pure Ti by two-step thermal oxidation using $\mathrm{N}_{2}$-CO gas. Mater. Trans. 54, 1302-1307. doi: 10.2320/matertrans. ME201315

Wang, F. E., Buehler, W. J., and Pickart, S. J. (1965). Crystal structure and a unique martensitic transition of TiNi. J. Appl. Phys. 36, 3232-3239. doi: $10.1063 / 1.1702955$

Wang, K., Gustavson, L., and Dumbleton, J. (1993). "Low modulus, high strength, biocompatible titanium alloy for medical implants, in Titanium'92: Science and Technology, eds F. H. Froes and H. L. Caplan (Warrenda, PA: TMS), 2697-2704.

Wang, X., Xu, S., Zhou, S., Xu, W., Leary, M., Choong, P., et al. (2016). Topological design and additive manufacturing of porous metals for bone scaffolds and orthopaedic implants: a review. Biomaterials 83, 127-141. doi: 10.1016/j.biomaterials.2016.01.012

Wang, Z., Wang, C., Li, C., Qin, Y., Zhong, L., Chen, B., et al. (2017). Analysis of factors influencing bone ingrowth into three-dimensional printed porous metal scaffolds: a review. J. Alloy. Comp. 717, 271-285. doi: 10. 1016/j.jallcom.2017.05.079

Waterstrat, R. M., Rupp, N. W., and Franklin, O. (1978). Production of a cast titanium-base partial denture. J. Dent. Res. 57:254.

Wennerberg, A., and Albrektsson, T. (2010). On implant surfaces: a review of current knowledge and opinions. Int. J. Oral Maxillofac Implant. 25, 63-74.

Westall, J., and Hohl, H. (1980). A comparison of electrostatic models for the oxide/solution interface. Adv. Colloid Interface Sci. 12, 265-294. doi: 10.1016/0001-8686(80)80012-1

William, D. F. (1987). "Definitions in biomaterials", in Proceedings of a Consensus Conference of the European Society for Biomaterials, Vol. 4 (Chester; New York, NY: Elsevier).

Williams, D. F. (1982a). "Titanium and titanium alloys," in Biocompatibility of Clinical Implant Materials, eds D. F. Williams (Boca Raton, FL: CRC Press), 10-44.

Williams, D. F. (1982b). "Biological effects of titanium," in Systematic Aspects of Biocompatibility, ed D. F. Williams (Boca Raton, FL: CRC Press), 170-177. 
Williams, R. (ed.). (2011). Surface Modification of Biomaterials. Cambridge, UK: Woodhead Publishing.

Yamaguchi, Y., Adachi, M., Iijima, M., Wakamatsu, N., Kamemizu, H., Omoto, S., et al. (2010). Thin carbonate apatite layer biomimetically-coated on SAMTi substrate surfaces. J. Ceram. Soc. Jpn. 118, 458-461. doi: 10.2109/jcersj2. 118.458

Yamamichi, N., Pugdee, K., Chang, W., Lee, S., and Yoshinari, M. (2008). Gene expression monitoring in osteoblasts on titanium coated with fibronectin-derived peptide. Dent. Mater. J. 27, 744-750. doi: 10.4012/dmj. 27.744

Yamamoto, D., Iida, T., Arii, K., Kuroda, K., Ichino, R., Okido, M., et al. (2012). Surface hydrophilicity and osteoconductivity of anodized $\mathrm{Ti}$ in aqueous solutions with various solute ions. Mater. Trans. 53, 1956-1961. doi: 10.2320/matertrans.M2012082

Zardiackas, L. D., Mitchell, D. W., and Disegi, J. A. (1996). "Characterization of Ti-15Mo beta titanium alloy for orthopaedic implant applications," in Medical Applications of Titanium and Its Alloys, eds S. A. Browns and J. E. Lemons (West Conshohoken, PA: ASTM), 60-75.
Zhan, H., Wang, G., Kent, D., and Dargusch, M. (2016). The dynamic response of metastable $\beta$ Ti-Nb alloy to high strain rates at room and elevated temperatures. Acta Mater. 105, 104-113. doi: 10.1016/j.actamat.2015.11.056

Zhang, J. Y., Li, J. S., Chen, Z., Meng, Q. K., Sun, F., and Shen, B. L. (2017). Microstructural evolution of a ductile metastable b titanium alloy with combined TRIP/TWIP effects. J. Alloys Compd. 699,775-782. doi: 10.1016/j.jallcom.201612.394

Conflict of Interest Statement: The author declares that the research was conducted in the absence of any commercial or financial relationships that could be construed as a potential conflict of interest.

Copyright $\odot 2019$ Hanawa. This is an open-access article distributed under the terms of the Creative Commons Attribution License (CC BY). The use, distribution or reproduction in other forums is permitted, provided the original author(s) and the copyright owner(s) are credited and that the original publication in this journal is cited, in accordance with accepted academic practice. No use, distribution or reproduction is permitted which does not comply with these terms. 